\title{
Conformational changes involved in SGC activation
}

\author{
Michael A Marletta ${ }^{1 *}$, Eric Underbakke ${ }^{1}$, Melody G Campbell ${ }^{2}$, Bridget Carragher ${ }^{2}$, Clinton S Potter ${ }^{2}$ \\ From 6th International Conference on cGMP: Generators, Effectors and Therapeutic Implications \\ Erfurt, Germany. 28-30 June 2013
}

\section{Background}

Soluble guanylate cyclase (sGC) is a central target of nitric oxide (NO) action. sGC is a heterodimeric hemoprotein. The ferrous heme efficiently traps NO and plays an intimate role in activation of the enzyme to catalyse the conversion of GTP to cGMP. sGC is also the target for cardiovascular therapies involving small molecules that stimulate sGC directly or activate oxidized or apo sGC. Efforts to fully characterize sGC catalysis have been hampered by the lack of structural information.
High-resolution structures of sGC fragments (domains) have been determined and have provided important detail; however, a structure of the full-length protein, an essential piece of the puzzle, remains unsolved.

\section{Results}

Using hydrogen-deuterium exchange-mass spectrometry (HDX-MS), higher order domain interactions have been mapped [1]. HDX-MS revealed direct interactions between the PAS domain and the heme-associated signaling helix of

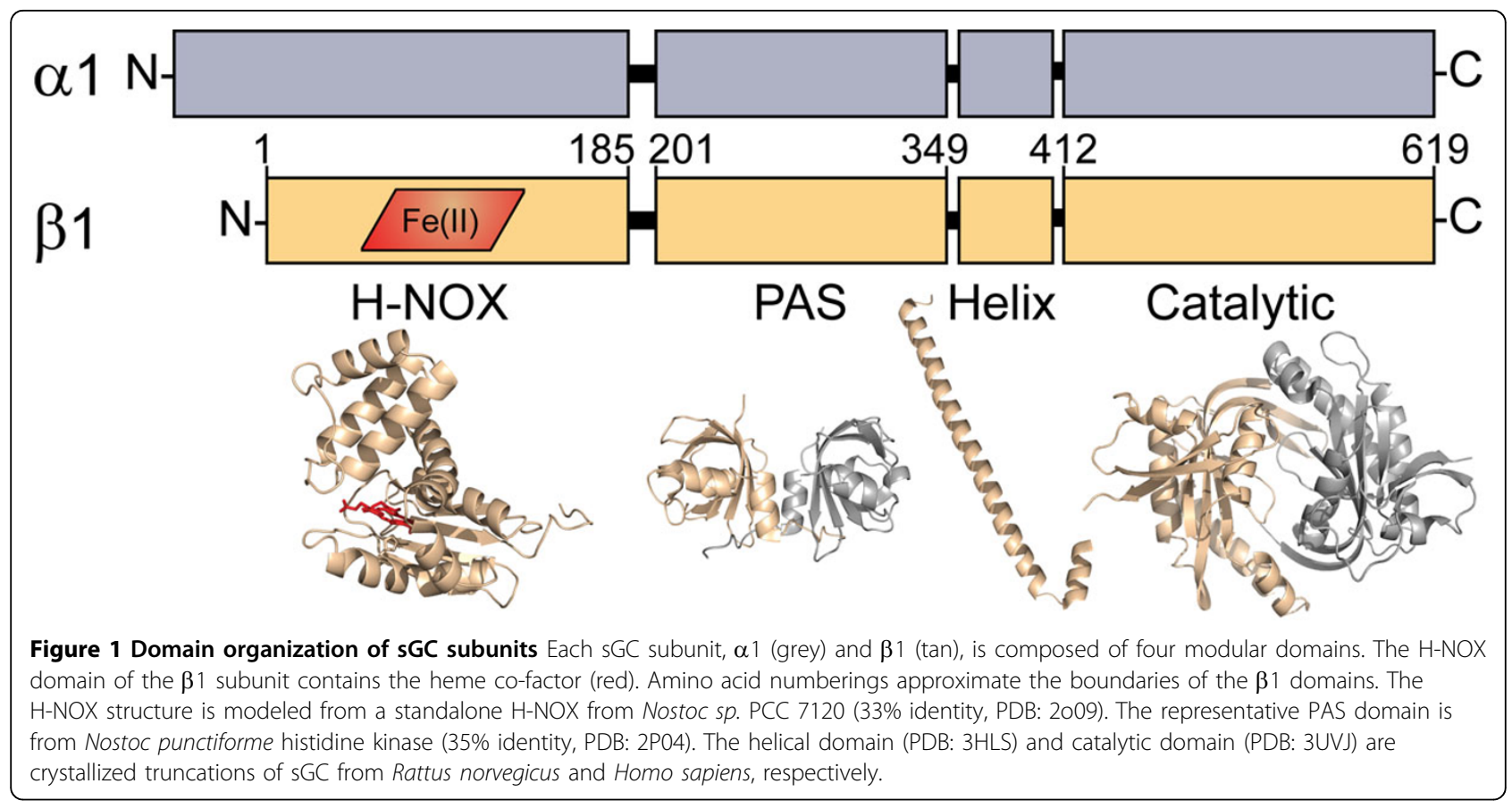

\footnotetext{
* Correspondence: marletta@scripps.edu

'Department of Chemistry, The Scripps Research Institute, La Jolla, California 92037, USA

Full list of author information is available at the end of the article
} 
the H-NOX domain. Furthermore, interfaces between the H-NOX and catalytic domains were mapped using domain truncations and full-length sGC. The H-NOX domain buries surfaces of the $\alpha 1$ catalytic domain proximal to the cyclase active site, suggesting a signaling mechanism involving NO-induced de-repression of catalytic activity. This method is now being extended to map the conformational changes that take place in sGC with NO binding and other small molecules that influence catalytic activity. In addition, significant advances toward a full-length structure have been obtained using single-particle electron microscopy.

\section{Conclusion}

Together these approaches define the architecture of the sGC holoenzyme, revealing inter-domain interactions responsible for communicating $\mathrm{NO}$-occupancy from the heme to the catalytic site. The resultant structural model of sGC provides insight into the mechanisms of activation of both $\mathrm{NO}$ and small molecule modulators.

\section{Authors' details}

'Department of Chemistry, The Scripps Research Institute, La Jolla, California 92037, USA. ²Department of Integrative Structural and Computational

Biology, The Scripps Research Institute, La Jolla, California 92037, USA.

Published: 29 August 2013

\section{Reference}

1. Underbakke $\mathrm{E}$, lavarone AT, Marletta MA: Higher-order interactions bridge the nitric oxide receptor and catalytic domains of soluble guanylate cyclase. Proc Natl Acad Sci U S A 2013, 110:6777-6782.

doi:10.1186/2050-6511-14-S1-012

Cite this article as: Marletta et al.: Conformational changes involved in sGC activation. BMC Pharmacology and Toxicology 2013 14(Suppl 1):012.

\section{Submit your next manuscript to BioMed Central} and take full advantage of:

- Convenient online submission

- Thorough peer review

- No space constraints or color figure charges

- Immediate publication on acceptance

- Inclusion in PubMed, CAS, Scopus and Google Scholar

- Research which is freely available for redistribution

Submit your manuscript at www.biomedcentral.com/submit 